\title{
EPISODIC DEPOSITION OF Mn MINERALS IN COCKADE BRECCIA STRUCTURES IN THREE LOW-SULFIDATION EPITHERMAL DEPOSITS: A MINERAL STRATIGRAPHY AND FLUID-INCLUSION APPROACH
}

\author{
JACQUES L. LEROY ${ }^{\S}$ AND DANIEL HUBÉ \\ Université Henri Poincaré, UMR G2R 7566, BP 239, F-54506 Vandoeuvre-lès-Nancy Cedex, France \\ ERIC MARCOUX ${ }^{\mathrm{II}}$ \\ BRGM, DR/RM, BP 6009, F-45060 Orléans Cedex, France
}

\begin{abstract}
Mineralogical and fluid-inclusion studies have been conducted on Mn-rich breccias from three low-sulfidation epithermal gold deposits, Cirotan (Indonesia), Orcopampa (Peru) and Cavnic (Romania). In these deposits, the manganiferous minerals occur within cockade breccias that precede most of the deposition of sulfide. Cockade breccias consist of a lithic or sulfide nucleus, a few centimeters across, encrusted by several concentric envelopes that can be subdivided into three successive zones. Each zone may be composed of several stacked sequences of deposition. The Mn minerals are mainly clustered within the internal pinkish zone close to the nucleus, that also comprises quartz, "adularia" and sparse sulfides. Within this Mn mineral zone, each sequence begins with the deposition of $\mathrm{Mn}$ silicate, close to the rhodonite end-member $\left(\mathrm{MnSiO}_{3}\right)$, that fully or partially grades into $\mathrm{Mn}$ carbonate, close to the rhodochrosite $\left(\mathrm{MnCO}_{3}\right)$ end-member, before the deposition of the next sequence. The intermediate zone (the quartz-sulfide zone) consists of quartz-sulfide sequences, with minor Mn silicates. Each sequence begins with finegrained quartz, indicating a high rate of nucleation, which becomes coarser grained and irregular at the end of the sequence. Chlorite and sulfides are associated with quartz at the end of this zone. The external zone of the cockades is characterized by comb quartz, associated with illite, calcite and, sparingly, manganoan dolomite. The mineralogical zonation illustrated by the cockades expresses a general evolution of the depositional process with time, with a progressive Mn-depletion and Ca-enrichment. No kutnohorite has been observed. Fluid inclusions from the three zones are all two-phase aqueous inclusions $(\mathrm{L}+\mathrm{V})$. The fluid salinities are similar in all the deposits and do not exceed $2.6 \mathrm{wt} \% \mathrm{NaCl}$ eq., the final comb quartz from Orcopampa excepted. Two isenthalpic boiling events are recorded in relation with brittle deformation. The replacement of rhodonite by rhodochrosite revealed in each sequence of the Mn mineral zone could result in a temperature drop in relation to these boiling events, which release $\mathrm{CO}_{2}$ and increase $\mathrm{pH}$.
\end{abstract}

Keywords: low-sulfidation epithermal deposit, cockade structure, rhodonite, rhodochrosite, fluid inclusions, boiling, Cirotan, Indonesia, Orcopampa, Peru, Cavnic, Romania.

\section{SOMMAIRE}

Les minéraux de manganèse, fréquemment présents dans les gisements d'or épithermaux, ont fait l'objet d'études minéralogiques et d'inclusions fluides dans trois gisements à faible teneur en soufre, Cirotan (Indonésie), Orcopampa (Pérou) et Cavnic (Roumanie). Dans ces gisements, les minéraux de manganèse apparaissent dans des brêches à cocardes qui précèdent l'essentiel du dépôt des minéraux métalliques. Les cocardes sont constituées d'un nucleus lithique ou sulfuré entouré d'enveloppes minérales regroupées en trois zones, chacune d'entre elles pouvant être constituées de plusieurs séquences comparables. Les minéraux de Mn, associés à quartz, adulaire et rares sulfures, se concentrent dans la zone interne de teinte rose, au contact des nucléus. Chaque séquence de cette zone à minéraux de $\mathrm{Mn}$ débute par des silicates de $\mathrm{Mn}$ proches du pôle rhodonite $\left(\mathrm{MnSiO}_{3}\right)$, qui sont ensuite remplacés partiellement ou totalement par des carbonates de $\mathrm{Mn}$ proches du pôle rhodochrosite $\left(\mathrm{MnCO}_{3}\right)$, avant la formation de la séquence suivante. La zone intermédiaire est constituées de plusieurs séquences successives à quartz et sulfures, avec rares silicates de manganèse. Elles débutent par du quartz à grain très fin témoignant d'une intense germination évoluant vers du quartz plus grossier. Cette zone intermédiaire s'achève par la cristallisation de quartz associé à chlorite et sulfures. La zone externe est à quartz columnaire, illite, calcite et dolomite manganésifère et est fréquemment géodique. Cette zonalité minéralogique autour des nucléus traduit une évolution globale du dépôt dans le temps, avec un appauvrissement progressif en

$\S \quad$ E-mail address: jacques.leroy@g2r.uhp-nancy.fr

Il Present address: Université d'Orléans, ESEM, 8, rue Léonard de Vinci, F-45072 Orléans Cedex 2, France. E-mail address: eric.marcoux@univ-orleans.fr 
Mn et un enrichissement en Ca. Aucun terme intermédiaire de type kutnohorite n'a cependant été observé. Les inclusions fluides analysées dans les trois zones sont toutes des inclusions aqueuses biphasées $(\mathrm{L}+\mathrm{V})$. Les salinités mesurées sont comparables et ne dépassent pas $2,6 \%$ en poids éq. $\mathrm{NaCl}$ (exception faite du quartz terminal à Orcopampa). Deux épisodes d'ébullition (isoenthalpique) ont été enregistrés en relation avec des épisodes de déformation cassante. La transformation rhodonite rhodochrosite observée dans les séquences de la zone à minéraux de manganèse pourrait résulter de la chute de la température des fluides consécutive à ces épisodes d'ébullition qui libèrent $\mathrm{CO}_{2}$ et élèvent le $\mathrm{pH}$.

Mots-clés: gîtes épithermaux neutres ou à faible teneur en soufre, structure en cocarde, rhodonite, rhodochrosite, inclusions fluides, ébullition, Cirotan, Indonésie, Orcopampa, Pérou, Cavnic, Roumanie.

\section{INTRODUCTION}

Manganiferous minerals are commonly associated throughout the world with precious and base-metal epithermal ore deposits of the "adularia-sericite type", also called "low sulfidation" type. These low-sulfidation epithermal deposits are related to fluid circulation associated with calc-alkaline magmatism at a depth of $0-2$ $\mathrm{km}$.

The chronological position of the Mn minerals is variable. They could be very early in the mineralogical sequence, such as in the Bulldog Mountain vein system, Creede District, Colorado (Plumlee \& WhitehouseVeaux 1994). In the Pongkor and Cirotan deposits, in western Java, Indonesia (Milési et al. 1994, 1999, Marcoux et al. 1993, 1996), the Mn minerals appeared just before the main stage of sulfide deposition. In the Cavnic mine, in the Baia Mare mining district, northern Romania, they crystallized with the base-metal minerals, before the main stage of deposition of stibnite and precious metals (Bailly et al. 1998, Grancea 1998, Piantone et al. 1999). The deposition of gold may be contemporaneous with that of the Mn minerals, as observed at Acupan in the Baguio District, Philippines (Cooke et al. 1996).

The Mn-bearing minerals commonly occur in mineralized breccias, and locally in cockade breccias. Despite their spectacular appearance, such structures have only rarely been described in detail in epithermal deposits, for example in the Cirotan deposit, Indonesia (Genna et al. 1996) and in the Orcopampa deposit, in Peru (Gibson et al. 1995). In these cockade breccias, the Mn minerals may form part of the silicate paragenesis, dominated by rhodonite $\left[\mathrm{MnSiO}_{3}\right]$ and bustamite $\left[(\mathrm{Mn}, \mathrm{Ca}, \mathrm{Fe}) \mathrm{SiO}_{3}\right]$ with minor rhodochrosite $\left[\mathrm{MnCO}_{3}\right]$, alabandite $[\mathrm{MnS}]$, barite and manganoan calcite, and a carbonate paragenesis, dominated by rhodochrosite, with common kutnohorite $\left[\mathrm{CaMn}\left(\mathrm{CO}_{3}\right)_{2}\right]$ and siderite.

Our aim in this paper is to establish the relationship of these Mn minerals with characteristics of the fluid phase, episodes of brittle failure and mineral deposition in cockade-shaped samples from the low-sulfidation type epithermal Cirotan deposit, in West Java. Complementary data were obtained from two other epithermal deposits, Cavnic, in the Baia Mare mining district, Romania, and Orcopampa, in Peru. In all three deposits, mineral deposition takes place in an open-space system along segments of faults.

\section{Geological Setting}

The Cirotan Pliocene gold deposit, in West Java, Indonesia, provides an exceptional example of a mineralized breccia (Genna et al. 1996). It is a mineralized strike-slip to normal fault, with ore shoots occurring within a system of fractures and open spaces. Mineralization has occurred in a single event, with five stages of deposition (Milési et al. 1994). This event began with silicification, followed by deposition of polymetallic sulfides and Mn minerals, and ended with deposition of precious metal and quartz. This evolution was accompanied by a progressive increase of $\mathrm{W}, \mathrm{Sn}, \mathrm{Au}$ and $\mathrm{Bi}$ content in the ore, which leads to the crystallization of ferberite, scheelite, cassiterite and gold; this increase is interpreted as being related to a progressive ascent of the underlying andesitic magma. The Cirotan deposit is composed of several stacked breccia units as infilling of a major normal fault. Each of these presents various facies, among which are siliceous breccias near the footwall of the structure, and large cockade breccias along the hanging wall of the vein (Fig.1).

The Orcopampa district is located in southern Peru, within a belt of intermediate to felsic calc-alkaline volcanic rocks of Neogene age. These rocks include ashflow tuffs, lava flows and volcanic breccias (Gibson $e t$ al. 1995). The mineralized veins are mainly hosted in east-northeast-striking conjugate normal faults. This system was active during and after deposition of the ore. The veins thus present a complex sequence of mineral deposition and hydrothermal brecciation, with five paragenetic stages recognized (Gibson 1992). Sulfides, mainly pyrite, sphalerite, galena, chalcopyrite, acanthite and sulfosalts form alternating bands and pods within banded and massive quartz, rhodonite and rhodochrosite. Most of the veins have an Ag:Au ratio of 1000 or more.

The $\mathrm{Au}-\mathrm{Cu}-\mathrm{Zn}-\mathrm{Pb}$ Cavnic vein system is located in the Baia Mare mining district, northern Romania. The Cavnic mine is composed of two fault systems: 1 ) a set of about 15 subparallel $\mathrm{N} 10-30^{\circ} \mathrm{E}$ breccia veins, approximately $100 \mathrm{~m}$ or so long, and $1 \mathrm{~m}$ thick (CavnicBoldut) within a NW-SE-oriented belt; the complex vein filling consists essentially of breccia showing metasomatic replacement and collapse features; 2) a N $100^{\circ} \mathrm{E}-$ striking system (Cavnic-Roata) that is discordant to the NE-SW veins. It consists of a system of veins with banded texture (Ana Nicolae), fairly polymetallic, with 


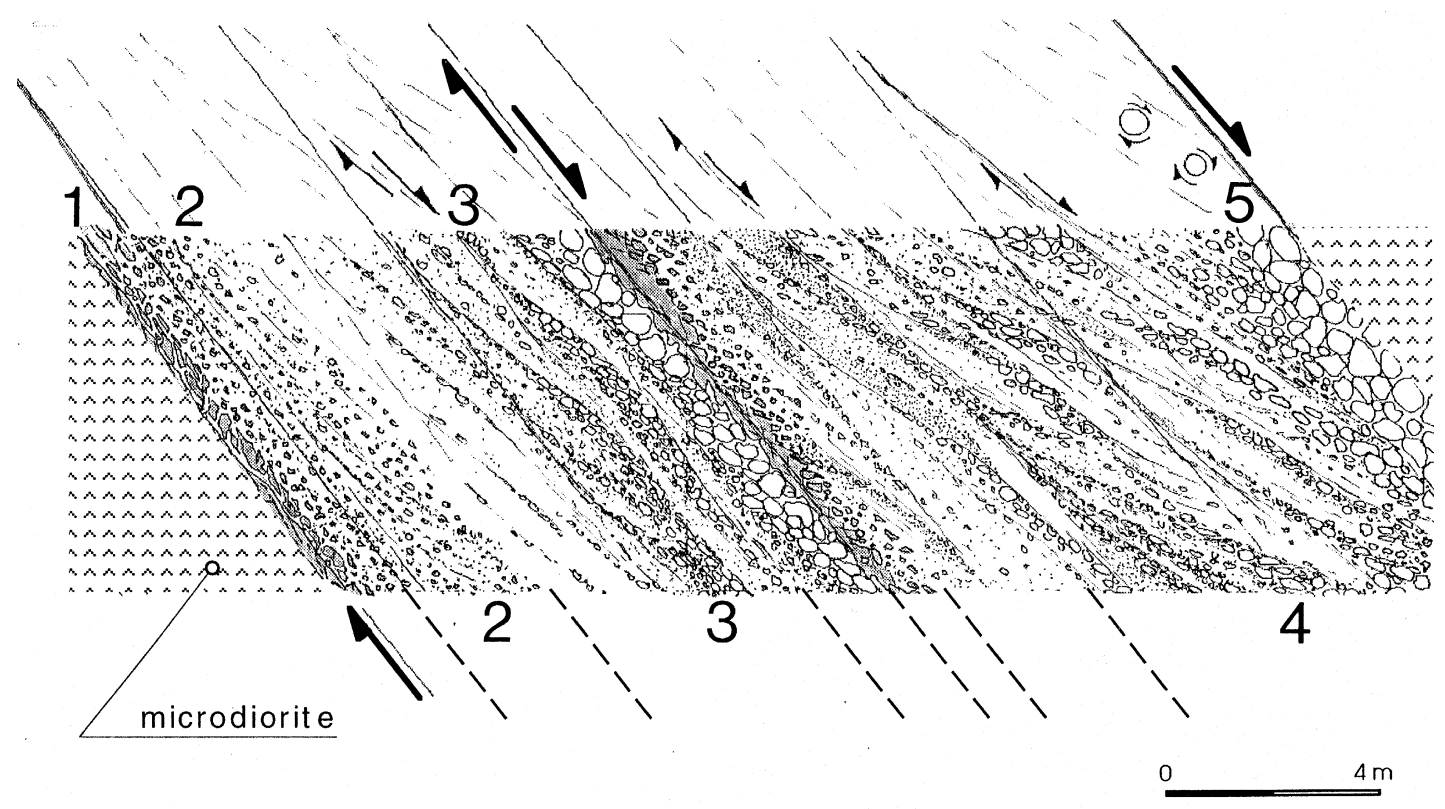

FIG. 1. General east-west cross section at level 1000 of a mineralized fault in the Cirotan deposit, showing geometry and related kinematics of the breccia units (after Genna et al. 1996). 1. Network of quartz veins in the footwall. 2. Siliceous breccias. 3. Small cockade breccias. 4. Large cockade breccias. 5. Stalagmites on the hanging wall.

gold-bearing mineralization. Ore deposition was related to intense hydrothermal activity and brecciation subsequent to the emplacement of a large Neogene rhyodacitic complex and associated dyke-swarms. Five stages of mineral deposition are distinguished, with Mn minerals during stage 4 , and precious metals during stage 5 .

\section{Structure and Mineralogy of the Mineralized Cockades}

\section{Structure of the cockades}

At Cirotan, the cockades range from small, centimeter-wide (elliptical cockades) to larger (up to $1 \mathrm{~m}$ ), more equant cockades with a reversely graded bedding from the footwall to the hanging wall (Figs.1, 2A). According to Genna et al. (1996), this cockade structure is interpreted to be the result of several rolling-accretion and collapse events in an open space, where high fluid pressure combined with local structural conditions maintained hydrothermal channelways, enabling cockade growth and collapse. Thus growth zones are related to a fracturing event, whereas discontinuous patterns along the rim are related to rotational movement during shearing. Ore deposition occurred during a pulsating hydrothermal process that was active throughout the complex evolution of the fault structure. This situation has led to striking textural and mineralogical variability. The cock- ade breccias from Orcopampa and Cavnic reveal a shorter history and thus a less complex structure.

Cockade breccias (Figs. 2B, 3) can be qualified as composite because of the great variability of the mineral assemblages and the complexity of the observed textures. Their structure comprises a central centimeter-size nucleus of fractured and altered volcanic rock (silicified dacite and rhyodacite at Cirotan and Orcopampa) (Figs. 4A, B), in some cases composed of an agglomeration of several smaller fragments of siliceous breccia, or of early metallic sulfides, mainly sphalerite (Cavnic) (Fig. 4C). The structure, the texture and the mineralogy of the nuclei are inherited from early magmatic, hydrothermal and tectonic events. The nuclei are encrusted by several concentric envelopes of hydrothermal minerals making up the cockade structure, up to $20 \mathrm{~cm}$ thick. These envelopes may be continuous or discontinuous, and usually present at the sample scale a mineralogical evolution with time, with dominant $\mathrm{Mn}$ bearing minerals encrusting the nuclei, followed by dominant quartz-sulfides, and then terminal comb quartz.

\section{The Mn-bearing mineral zone}

In the deposits studied, the Mn minerals (Figs. 2C to $\mathrm{F}$ ) are the dominant minerals in the first envelopes around the nuclei. The $\mathrm{Mn}$ minerals occur as fine 

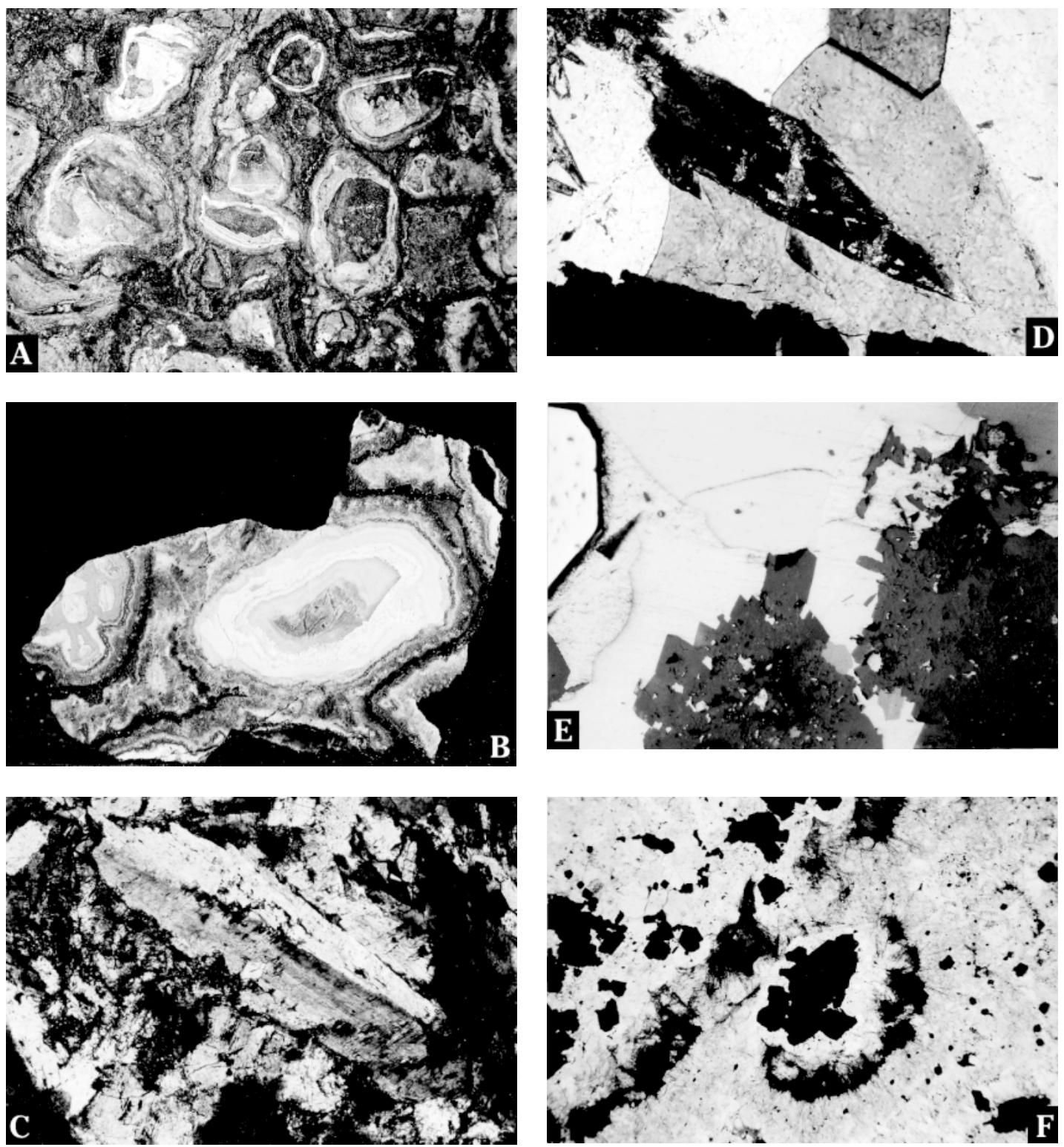

FIG. 2. A. Cockade breccia from the Cirotan gold mine (1000 m level). The approximate size of the two biggest cockades is $10 \mathrm{~cm}$. B. Polished fragment of one cockade (Cirotan mine) showing a nucleus made of volcanic rock and translucent silica, the Mn minerals zone (pinkish, with pinkish envelopes corresponding to sequences of deposition), the quartz-sulfide zone (coalescent translucent zone bounded by black minerals), and the final generation of comb quartz, which is common to several cockades occupying the space between them. Size of the fragment: $15 \mathrm{~cm}$. C. Twinned crystal of rhodonite (Mn mineral zone; Cirotan mine). Crystal size: $0.5 \mathrm{~mm}$. D. Idiomorphic crystal of rhodonite (dark gray) partially replaced by rhodochrosite (white and blue zones) (Mn mineral zone; Orcopampa mine). Size of rhodonite crystal: $1 \mathrm{~mm}$. E. Late sequence of the Mn mineral zone: the rhodonite (dark gray porous zone) is partially replaced by rhodochrosite (dark gray rhombohedral crystals) and coated by sulfides: chalcopyrite (yellow), galena: (scratched gray), tetrahedrite: (gray), pyrite: (white). (Orcopampa mine). Photograph width: $2 \mathrm{~mm}$. F. Fibrous aggregates of Mn silicates (inesite and rhodonite) surrounding pyrite crystals (black). White translucent mineral is quartz (quartz-sulfide zone, Cirotan mine). Size of the central aggregate of pyrite: $1 \mathrm{~mm}$. 


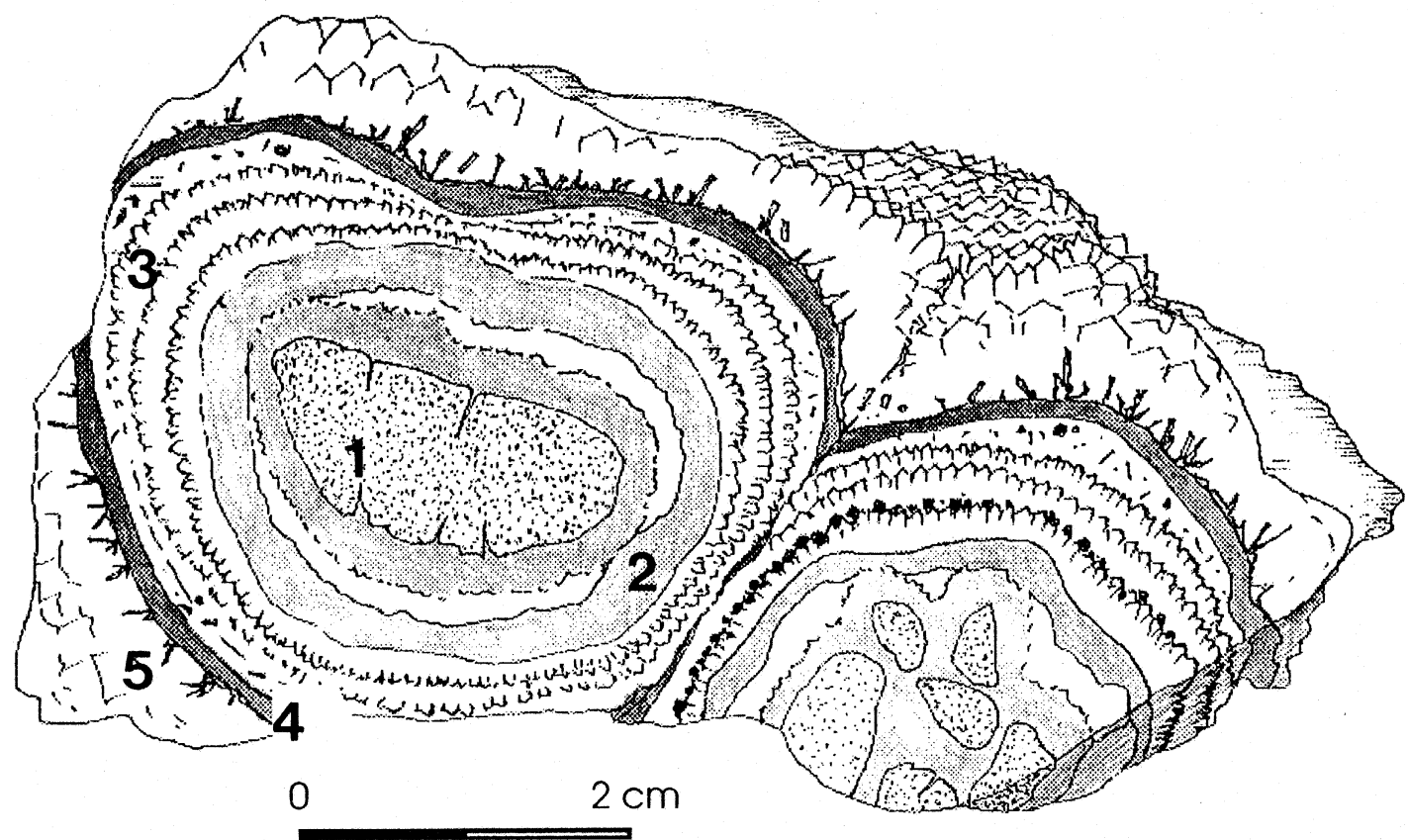

FIG. 3. Sample CN16 (Cirotan deposit) showing a typical cockade structure. 1. Nucleus of altered and silicified volcanic rock. 2. Pink to brownish pink aphanitic Mn-bearing mineral zone. 3. Dominant quartz-sulfide zone with concentric and repeated sequences displaying a geopetal structure. 4. Honey-colored collomorph sphalerite and pyrite pseudomorphs after pyrrhotite. 5. Final generation of comb quartz.

grained to aphanitic, pink to brownish, concentric rims, and are composed of Mn silicates and Mn carbonates.

At Cirotan (Fig. 4A), the earliest rhodonite forms a chaotic network of millimetric needle-like crystals with comb quartz and minor rhodochrosite. Quartz crystals are small (less than $1 \mathrm{~mm}$ in size), milky, and platy, and display a regular syntactic comb texture perpendicular to the nucleus, demonstrating an open-space filling. Sheet silicates with compositions close to those of $\mathrm{Mg}-$ Mn-rich chlorite (clinochlore-pennantite solid solution) and platy calcite are present between the rhodonite laths. Textural relations indicate that rotational movements of the cockade have occurred during the precipitation of the Mn-bearing minerals. Conversely, at Orcopampa (Fig. 4B) and Cavnic (Fig. 4C), the rhodonite appears as prisms up to $1 \mathrm{~mm}$ in length, with two cleavage planes or twin planes in some well-preserved euhedral sections. Crystal aggregates have a comb to radial disposition around the nucleus of the cockades. At Orcopampa, the earliest rhodonite is associated with K-feldspar of "adularia" habit and large crystals of platy quartz.

A second envelope with fine-grained and turbid rhodochrosite and sulfides surrounds the first rhodonite - K-feldspar envelope, cutting and partly overprinting the rhodonite crystals. The Mn carbonates are pseudomorphic after the Mn silicates, mostly as skeletal to chaotic aggregates. They have crystallized according to the main crystallographic directions of the prismatic silicate crystals. The sulfides are mainly pyrite, tetrahedrite and sphalerite, with minor argentite and galena. The $\mathrm{Zn}$ sulfide has a composition close to end-member sphalerite, $\left(\mathrm{Zn}_{x} \mathrm{Mn}_{1-x} \mathrm{~S}\right.$, with $\left.0.90<x<0.93\right)$, and the tetrahedrite is zincian, $\left(\mathrm{Cu}_{x} \mathrm{Zn}_{y} \mathrm{Ag}_{1-x-y}\right)_{\Sigma 3}\left(\mathrm{Sb}_{z} \mathrm{As}_{1-z}\right) \mathrm{S}_{3}$, with $x$ $+y=1,0.8<x<0.83,0.1<y<0.16$ and $z=0.9$. Blebs of stromeyerite $[\mathrm{AgCuS}]$ were recognized in galena. Tellurium has been detected in patches of stromeyerite and could correspond to fine inclusions of silver- or copper-rich tellurides, possibly hessite $\left[\mathrm{Ag}_{2} \mathrm{Te}\right]$, empressite $\left[\mathrm{Ag}_{2-x} \mathrm{Te}_{1+x}\right]$, weissite $\left[\mathrm{Cu}_{2-x} \mathrm{Te}\right]$, rickardite $\left[\mathrm{Cu}_{7} \mathrm{Te}_{5}\right]$, or other Te-minerals.

At Cirotan, rhodonite without "adularia" also precipitated later, after rhodochrosite, and displays a comb to drusy growth-texture. Remnant open-spaces of the vugs are filled with milky quartz in some samples without rhodonite. The occurrence of early rhodonite in this first envelope is suggested by the prismatic to lozengeshaped habits of patches of quite pure Mn carbonate, in a matrix of carbonates closely associated with quartz and $\mathrm{Mn}$ silicates. A quartz-rich septum separates these carbonates from the rhodonite-rhodochrosite matrix and thus outlines the shape of replaced rhodonite crystals. 


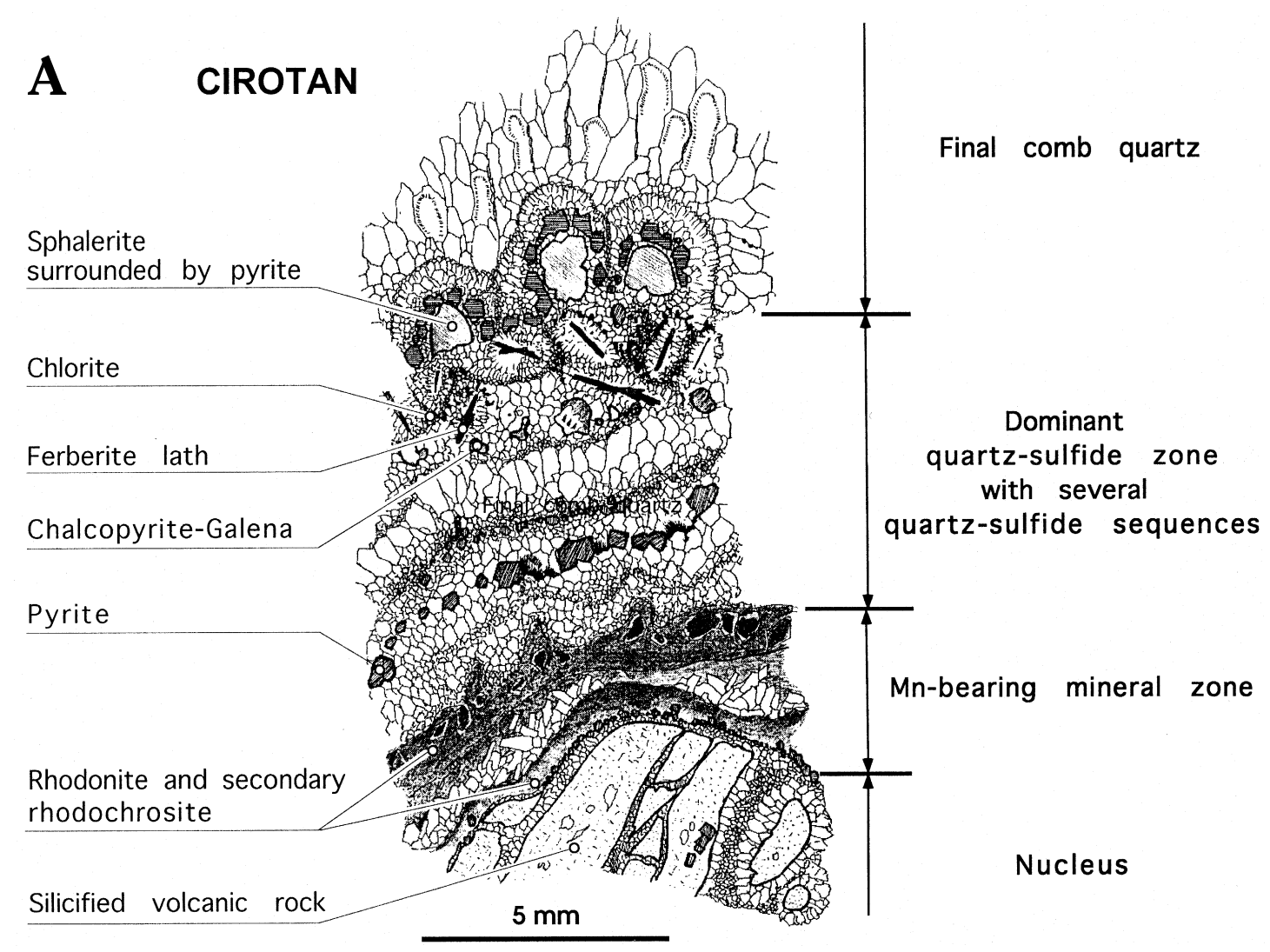

FIG. 4. Sketch drawings of the cockade from Cirotan (A), Orcopampa (B) and Cavnic (C) deposits.

\section{The dominant quartz-sulfide zone}

The dominant Mn-bearing mineral zone is followed by a second zone where quartz and sulfides prevail. This second zone is best represented in the Cirotan samples. This zone has a banded texture, which consists of alternating repeated sequences of quartz and sulfides, and has gradations in mineralogy, shape, and size from the beginning to the end of each sequence. At the beginning of each sequence, quartz is fine grained with irregular, lobate and ameboid textures, whereas at the end of each sequence, it appears as medium- to coarsegrained, regular, polygonal crystals. The relative abundance of sulfides varies from the first sequences, where euhedral to subhedral pyrite is dominant, to the most peripheral ones, where chalcopyrite and then sphalerite become more abundant. Radial, fibrous aggregates of brownish Mn silicates are observed around pyrite crystals at the inner part of this zone.

In one sample from Cirotan deposit, the last quartzsulfide band consists of an assemblage of fine-grained quartz, Fe-rich chlorite, and minor pyrite as inclusions in quartz. This assemblage is overlain by zoned colloform honey-colored sphalerite with galena inclusions and then by prismatic aggregates of pyrite. This pyrite was interpreted by Marcoux et al. (1993) as a pseudomorph of early pyrrhotite. In another sample, euhedral pyrite and clear comb quartz coat patches of sphalerite, underlain by an assemblage of quartz - chalcopyrite - galena - minor pyrite with occurrences of sparse tiny laths of polycrystalline ferberite.

\section{Final comb quartz and associated minerals}

The last envelopes of the cockades are characterized by the occurrence of comb quartz. At Cavnic and Orcopampa, the quartz crystals are commonly "turbid", owing to the presence of abundant scattered dust-like particles of carbonates that may outline the internal "ghost" crystals. The "angel wings" habit is common at Cirotan. Quartz is commonly intergrown with a) sheet silicates that are close to illite in composition at Cirotan, or b) zoned rhombs of manganoan dolomite at Cavnic. The remaining spaces are filled with calcite. 
B

ORCOPAMPA

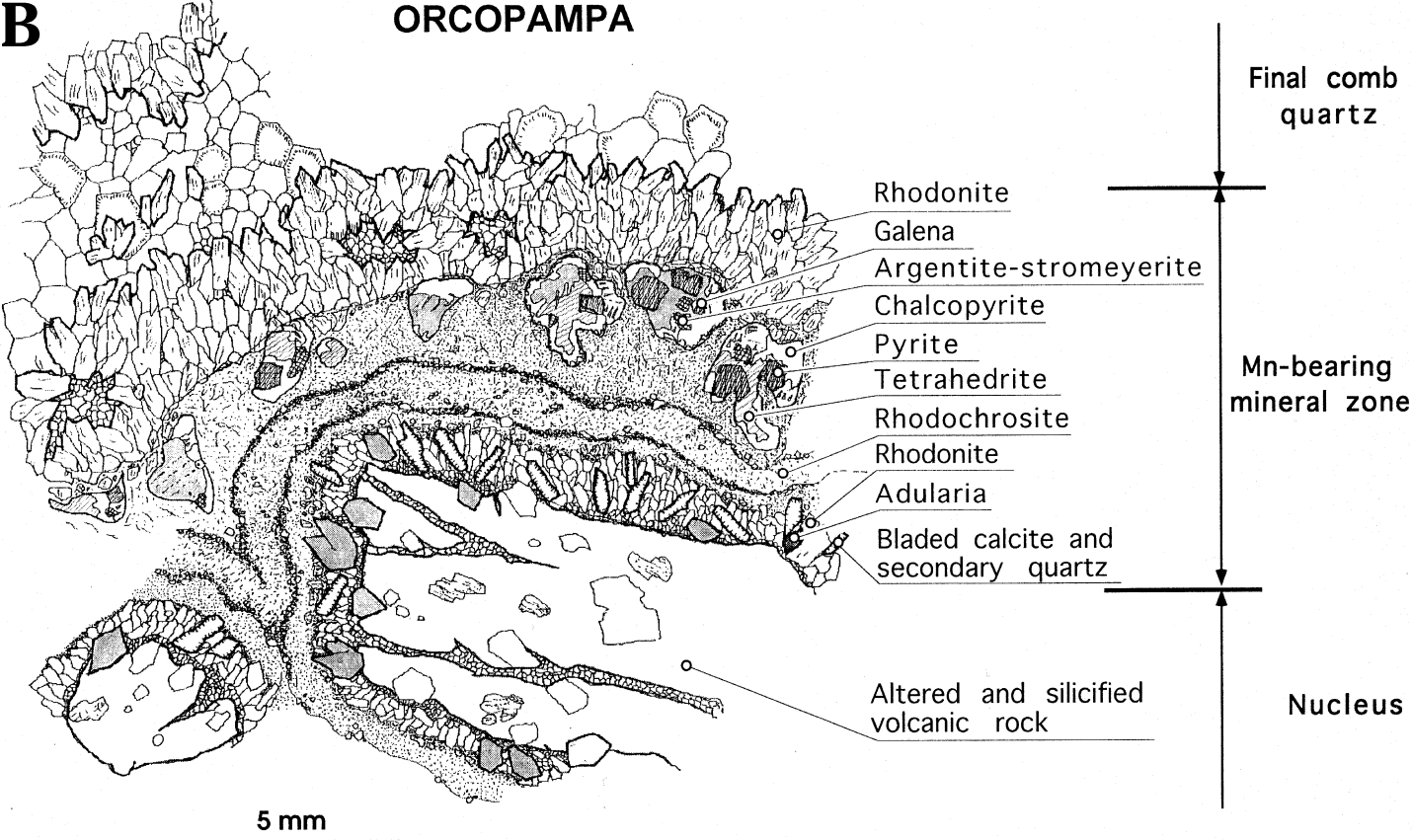

C

Primary calcite and dolomite

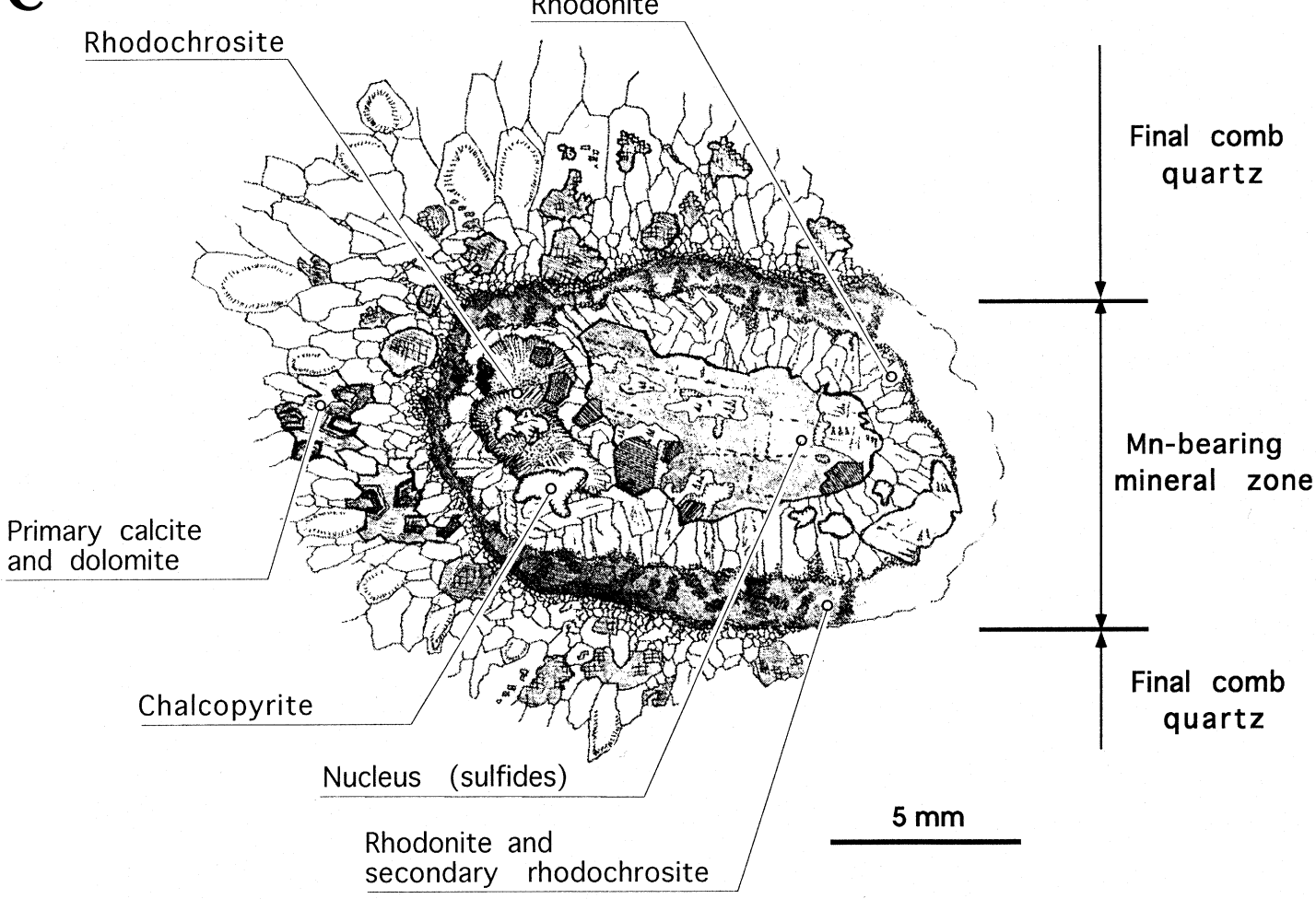

\section{CAVNIC}



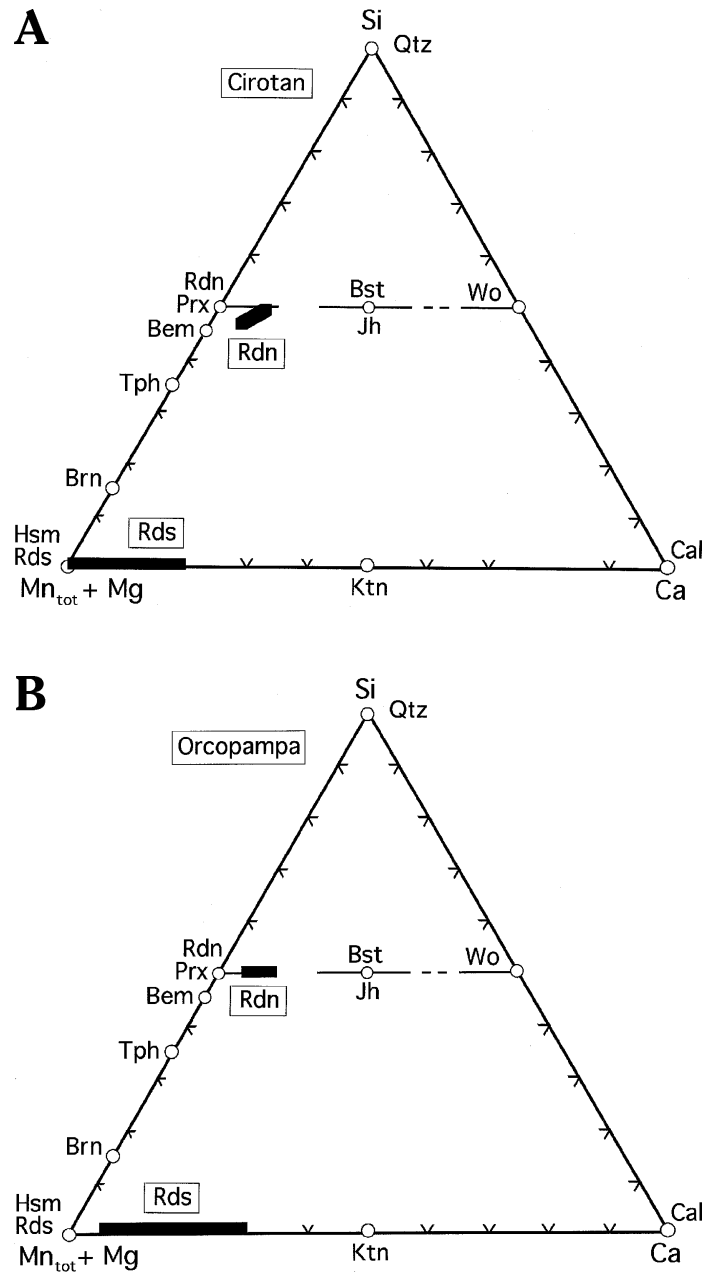

The whole hydrothermal genesis of cockades can be viewed as a single depositional sequence with 1) Mnbearing minerals, 2) quartz-sulfides and 3) comb quartz. In detail, this sequence is built up of microsequences. Each microsequence exhibits the same mineralogical succession as the overall sequence, with changes in relative abundance of minerals at the sequence scale resulting in the three-step mineralogical succession at the cockade scale described above.

\section{Chemical Composition of the Mn Minerals}

Chemical analyses of Mn minerals (silicates and carbonates) were carried out with a CAMECA SX-50 electron microprobe, after SEM observations of the same minerals by scanning electron microscopy. Chemical compositions were then interpreted using a $\mathrm{Si}-$ $\left(\mathrm{Mn}_{\text {tot }}+\mathrm{Mg}\right)-\mathrm{Ca}$ diagram (Lucchetti 1991) (Fig. 5).

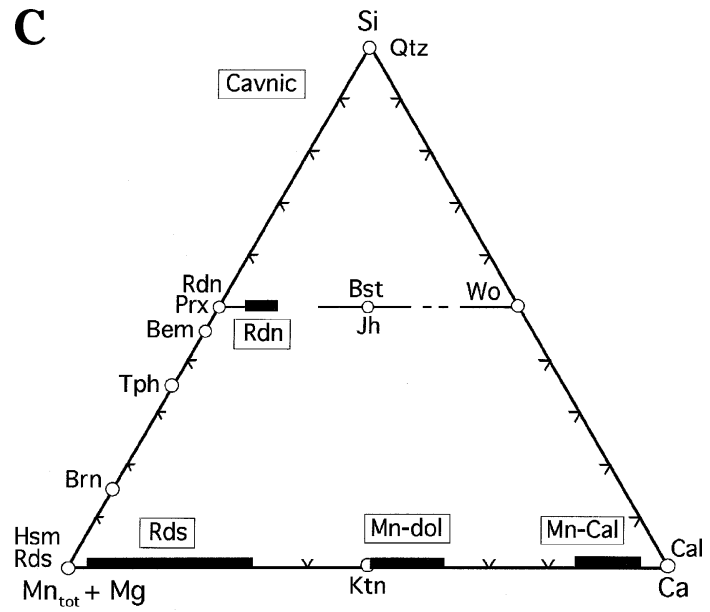

FIG. 5. $\mathrm{Si}-\left(\mathrm{Mn}_{t o t}+\mathrm{Mg}\right)-\mathrm{Ca}$ diagram (Lucchetti 1991) for Mn silicates, Mn carbonates and other carbonates from Cirotan (A), Orcopampa (B) and Cavnic (C) deposits. Bem: bementite, Brn: braunite, Bst: bustamite, Cal: calcite, Hsm: hausmanite, Ktn: kutnohorite, Jh: johansennite, Prx: pyroxmangite, Qtz: quartz, Rdn: rhodonite, Rds: rhodochrosite: Tph: tephroite, and Wo: wollastonite.

\section{The Mn silicate}

The Mn silicate, at Cavnic and Orcopampa deposits, is rhodonite with a $\mathrm{Ca}$ content ranging from 3.7 to 8 wt $\% \mathrm{CaO}$ (average value: $5.8 \mathrm{wt} \% \mathrm{CaO}$ ) at Cavnic and from 3.5 to $8.4 \mathrm{wt} \% \mathrm{CaO}$ (average value: $6.6 \mathrm{wt} \% \mathrm{CaO}$ ) at Orcopampa (Table 1). Only traces of $\mathrm{Fe}$ and $\mathrm{Mg}$ are observed in the rhodonite in both deposits: $0.4 \mathrm{wt} \% \mathrm{FeO}$ (range of $0-0.7 \mathrm{wt} \%$ ) and $0.6 \mathrm{wt} \% \mathrm{MgO}(0.2-0.8 \mathrm{wt} \%$ ) at Cavnic, and $0.25 \mathrm{wt} \% \mathrm{FeO}(0-0.6 \mathrm{wt} \%)$ and $0.4 \mathrm{wt} \%$ $\mathrm{MgO}(0-0.7 \mathrm{wt} \%)$ at Orcopampa. In the $\mathrm{Si}-\left(\mathrm{Mn}_{t o t}+\right.$ $\mathrm{Mg}$ ) - Ca diagram (Figs. 5B, C), all the analytical points define a horizontal line near the stoichiometric composition of rhodonite.

At Cirotan, the rhodonite is similar to the rhodonite analyzed in the two other deposits, but it is very difficult to get good analyses of rhodonite, which confirms microscopic observations and the common transformation of rhodonite. The analytical points correspond to $\mathrm{Mn}$ silicates more or less hydrated or transformed into carbonates, with a decrease in $\mathrm{SiO}_{2}, \mathrm{CaO}$ and $\mathrm{FeO}$ content and an increase in $\mathrm{MnO}$ content. In the triangular $\mathrm{Si}-\left(\mathrm{Mn}_{\text {tot }}+\mathrm{Mg}\right)-\mathrm{Ca}$ diagram (Fig. 5A), these analytical points are located along a rhodonite - bementite $\left[\left(\mathrm{Mn}_{8} \mathrm{Si}_{6} \mathrm{O}_{15}\right)(\mathrm{OH})_{10}\right]$ line. This result confirms the presence of hydrated $\mathrm{Mn}$ silicates, such as parsettensite $\left[(\mathrm{K}, \mathrm{Na}, \mathrm{Ca})(\mathrm{Mn}, \mathrm{Al})_{7} \mathrm{SiO}_{8} \mathrm{O}_{20}(\mathrm{OH})_{8}, 2 \mathrm{H}_{2} \mathrm{O}\right]$, determined by $\mathrm{X}$-ray diffraction, and illustrates the transformation of rhodonite according to the possible reaction: 
TABLE 1. COMPOSITION OF Mn SILICATES, Mn CARBONATES AND OTHER CARBONATES, FROM THE CIROTAN, ORCOPAMPA AND CAVNIC EPITHERMAL DEPOSITS

\begin{tabular}{|c|c|c|c|c|c|c|c|c|}
\hline & $\mathrm{SiO}_{2}$ & $\mathrm{Al}_{2} \mathrm{O}_{3}$ & $\mathrm{MnO}$ & $\mathrm{FeO}$ & $\mathrm{MgO}$ & $\mathrm{ZnO}$ & $\mathrm{CaO}$ & total \\
\hline \multicolumn{9}{|c|}{ Mn silicates } \\
\hline \multirow{7}{*}{$\begin{array}{l}\text { Cirotan } \\
\text { rhodonite }\end{array}$} & & & & & & & & \\
\hline & 45.81 & 0.46 & 46.97 & 0.45 & 0.75 & & 4.44 & 98.88 \\
\hline & 46.50 & 0.36 & 45.51 & 0.55 & 0.33 & & 6.67 & 99.92 \\
\hline & 45.41 & 0.34 & 45.48 & 0.35 & 0.40 & & 5.51 & 97.49 \\
\hline & 42.93 & 0.38 & 48.84 & 0.59 & 0.40 & 0.21 & 3.50 & 96.85 \\
\hline & 44.60 & 0.40 & 49.42 & 0.64 & 0.31 & & 3.52 & 98.89 \\
\hline & 46.21 & 0.38 & 44.61 & 0.24 & 0.26 & & 7.62 & 99.32 \\
\hline \multirow{8}{*}{$\begin{array}{l}\text { Cavnic } \\
\text { rhodonite }\end{array}$} & & & & & & & & \\
\hline & 46.32 & 0.22 & 47.80 & 0.59 & 0.58 & & 4.54 & 100.05 \\
\hline & 46.39 & 0.19 & 48.28 & 0.15 & 0.43 & & 5.36 & 100.80 \\
\hline & 46.25 & 0.58 & 48.22 & 0.41 & 0.49 & & 4.31 & 99.98 \\
\hline & 46.74 & 0.03 & 45.97 & 0.60 & 0.49 & & 6.07 & 99.90 \\
\hline & 46.19 & 0.52 & 46.09 & 0.49 & 0.51 & & 6.38 & 100.20 \\
\hline & 45.98 & 0.30 & 46.71 & 0.45 & 0.56 & & 5.93 & 99.93 \\
\hline & 46.45 & 0.37 & 46.85 & 0.39 & 0.44 & & 5.98 & 100.48 \\
\hline \multirow{8}{*}{$\begin{array}{c}\text { Orcopampa } \\
\text { rhodonite }\end{array}$} & & & & & & & & \\
\hline & 47.49 & 0.16 & 45.08 & 0.36 & 0.29 & & 6.55 & 99.93 \\
\hline & 46.58 & 0.56 & 45.66 & 0.20 & 0.31 & 0.05 & 7.54 & 100.85 \\
\hline & 46.36 & 0.57 & 44.32 & & 0.32 & & 8.22 & 99.79 \\
\hline & 46.55 & 0.43 & 45.69 & 0.10 & 0.18 & & 7.53 & 100.48 \\
\hline & 46.76 & 0.06 & 45.19 & 0.60 & 0.37 & & 7.11 & 100.09 \\
\hline & 47.10 & 0.06 & 44.58 & 0.14 & 0.56 & & 7.62 & 100.06 \\
\hline & 46.83 & 0.49 & 43.03 & 0.27 & 0.45 & & 8.38 & 99.45 \\
\hline \multicolumn{9}{|c|}{ Mn carbonates } \\
\hline \multicolumn{9}{|l|}{ Cirotan } \\
\hline rhodochrosite & e 0.59 & 0.08 & 49.30 & 0.64 & 0.19 & 1.25 & 6.43 & 58.49 \\
\hline & 0.32 & 0.05 & 50.19 & 1.04 & 0.11 & 1.04 & 6.75 & 59.84 \\
\hline & 0.28 & 0.04 & 45.77 & 1.44 & 0.16 & 1.44 & 7.57 & 57.46 \\
\hline & 0.49 & 0.03 & 51.87 & 3.26 & 0.03 & 2.85 & 0.56 & 59.18 \\
\hline \multicolumn{9}{|l|}{ Cavnic } \\
\hline rhodochrosite & e 0.04 & 0.02 & 54.53 & 0.60 & 0.26 & & 4.41 & 59.87 \\
\hline & 0.48 & & 39.45 & 0.47 & 0.63 & & 15.54 & 56.63 \\
\hline & 0.70 & 0.21 & 48.74 & 0.39 & 1.08 & 0.13 & 7.59 & 58.92 \\
\hline & 0.19 & 0.01 & 43.28 & 0.28 & 0.60 & & 14.66 & 59.04 \\
\hline \multicolumn{9}{|l|}{ Orcopampa } \\
\hline \multirow[t]{2}{*}{ rhodochrosite } & & & 48.91 & 0.19 & 0.58 & & 8.21 & 57.93 \\
\hline & 0.06 & & 45.45 & 0.22 & 0.24 & 0.09 & 10.91 & 56.99 \\
\hline \multicolumn{9}{|c|}{ Other Carbonates } \\
\hline \multirow{5}{*}{$\begin{array}{l}\text { Cavnic } \\
\text { manganoan } \\
\text { dolomite }\end{array}$} & & & & & & & & \\
\hline & & 0.09 & 14.32 & 0.59 & 9.79 & & 28.43 & 53.37 \\
\hline & & & 14.95 & 0.56 & 9.45 & & 28.44 & 53.61 \\
\hline & 0.16 & 0.09 & 7.07 & 6.20 & 10.43 & & 32.86 & 57.40 \\
\hline & 0.01 & & 7.68 & 5.97 & 11.00 & & 32.34 & 57.63 \\
\hline \multirow{4}{*}{$\begin{array}{l}\text { manganoan } \\
\text { calcite }\end{array}$} & & 0.01 & 8.74 & 0.10 & 0.09 & 0.07 & 51.13 & 60.80 \\
\hline & 0.01 & 0.05 & 5.10 & 0.07 & 0.03 & & 54.64 & 60.90 \\
\hline & 0.02 & 0.01 & 18.40 & & 0.10 & & 40.32 & 59.30 \\
\hline & & & 24.34 & & 0.36 & 0.04 & 30.90 & 55.71 \\
\hline
\end{tabular}

Selected chemical compositions obtained by automated CAMECA SX-50 electronmicroprobe.analysis.

$$
\begin{aligned}
& 9 \mathrm{MnSiO}_{3}+\mathrm{CO}_{2}+5 \mathrm{H}_{2} \mathrm{O} \\
& \text { rhodonite } \\
& =\underset{8}{\mathrm{Mn}_{8} \mathrm{Si}_{6} \mathrm{O}_{15}(\mathrm{OH})_{10}+\mathrm{MnCO}_{3}+3 \mathrm{SiO}_{2}} \\
& \text { bementite rhodochrosite quartz }
\end{aligned}
$$

The $\mathrm{Mn}$ and $(\mathrm{Ca}, \mathrm{Mn}, \mathrm{Mg})$ carbonates

The analyzed carbonate minerals can be roughly divided into two compositional groups, a rhodochrosite group with $\mathrm{Mn}$ dominant and a calcite group with $\mathrm{Ca}$ dominant (Fig. 5).

All the carbonates of the rhodochrosite group result from the replacement of rhodonite. The manganese carbonates from Cavnic and Orcopampa deposits are very similar. They are calcian rhodochrosite, with a $\mathrm{CaCO}_{3}$ content ranging from 5 to 30 mole $\%$. At Cirotan, the calcian rhodochrosite is poorer in $\mathrm{Ca}$. Its $\mathrm{CaCO}_{3}$ content does not exceed 18 mole \%. Traces of $\mathrm{Fe}$ and $\mathrm{Zn}$ are observed only at Cirotan, up to $3.3 \mathrm{wt} \% \mathrm{FeO}$ and $4.2 \mathrm{wt} \% \mathrm{ZnO}$, with a good positive correlation between these two elements and an average $\mathrm{FeO}: \mathrm{ZnO}$ of 0.7. At Cavnic and Orcopampa, the rhodochrosite is richer in $\mathrm{Mg}$, up to 2.7 and $1.4 \mathrm{wt} \%$, respectively. Only traces of $\mathrm{Mg}$ are observed in rhodochrosite from Cirotan.

The calcite group is observed only at Cavnic, in the last envelope of the cockades; these carbonates are considered to be primary. Their composition ranges widely from pure calcite to manganoan calcite (up to 15 mole $\% \mathrm{MnCO}_{3}$ ). Manganoan dolomite is also observed at Cavnic, but kutnohorite is not observed.

\section{Fluid-InClusion StUdiES}

At Cirotan, the fluid inclusions were studied in quartz from the three mineralogical zones previously defined, whereas at Cavnic and Orcopampa, only the final comb quartz was studied. All these inclusions are located along the growth zones of the quartz (primary inclusions). They are all two-phase aqueous inclusions $(\mathrm{L}+\mathrm{V})$, and no clathrate was observed. Because of the small size of the inclusions, eutectics could not always be precisely determined, and fluid salinities were determined using the $\mathrm{NaCl}-\mathrm{H}_{2} \mathrm{O}$ system (Bodnar 1993).

\section{The Mn-bearing mineral zone (Cirotan)}

The abundance of fluid inclusions increases from inner to outer part of this zone, where quartz crystallized with Mn-bearing minerals. The volume ratio V/L (vapor/liquid) is highly variable. Liquid-dominant inclusions, the most numerous, coexist with vapor-dominant ones. Because of the lack of evidence for necking down, this coexistence is interpreted as an indication of fluid boiling. It is supported by the presence of platy calcite. Inclusions homogenize either to liquid at temperatures ranging from 162 to $300^{\circ} \mathrm{C}$, or to vapor from 360 to $380^{\circ} \mathrm{C}$. The salinity of the fluid is rather low, between 1.4 and $2 \mathrm{wt} \%$ equiv. $\mathrm{NaCl}$.

\section{The quartz-sulfide zone (Cirotan)}

Inclusions were studied in the first sequence of this zone in contact with the Mn-bearing minerals zone. Only liquid-dominant inclusions with a rather constant $\mathrm{V} / \mathrm{L}$ value are observed, which indicates that a singlephase fluid was present during trapping (no boiling). Their homogenization temperatures (to liquid) increase 
from earlier to later in this sequence. They are between 167 and $200^{\circ} \mathrm{C}$ at the beginning of the sequence, in finegrained quartz, and between 215 and $316^{\circ} \mathrm{C}$, with a mean value around $250-255^{\circ} \mathrm{C}$, near the outer part of the sequence, in millimeter-size clear quartz in contact with pyrite. The salinity of the fluid is rather constant for all these inclusions, $1-2.2 \mathrm{wt} \%$ equiv. $\mathrm{NaCl}$.

\section{Final comb-quartz, zone (Cirotan, Orcopampa, Cavnic)}

At the base of the final comb-quartz zone from Cirotan, the coexistence of both liquid- and vapor-dominant inclusions indicates a boiling of the fluids at the beginning of this episode of quartz growth. The salinity of the fluid is around 1.9 wt.\% equiv. $\mathrm{NaCl}$. The inclusions homogenize to liquid at temperatures ranging from 180 to $287^{\circ} \mathrm{C}$ and to vapor between 257 and $377^{\circ} \mathrm{C}$.

At Cavnic and Orcopampa, liquid-dominant inclusions with a variable V/L value are also present in similar quartz. They homogenize to liquid at temperatures between 255 and $315^{\circ} \mathrm{C}$ at Cavnic and between 230 and $355^{\circ} \mathrm{C}$ at Orcopampa. The salinity of these fluids is between 1.9 and 6.9 wt. $\% \mathrm{NaCl}$ eq and 1.4 and 2.6 wt.\% $\mathrm{NaCl}$ eq., respectively.

\section{DISCUSSION}

Deciphering of mineral succession, correlated with fluid-inclusion data, gives a rather complete record of the history of mineralized cockades and thus sheds some light onto the significance of Mn-bearing minerals in the genesis of low-sulfidation ore deposits.

Rhodonite and rhodochrosite are common in most low-sulfidation epithermal deposits. We have documented the early appearance of Mn silicates in the depositional history of these three ore deposits. Textural observations, such as pseudomorphs of $\mathrm{MnCO}_{3}$ after rhodonite, both showing the same levels of $\mathrm{Ca}$ and $\mathrm{Mg}$, and the "ghosts" of prismatic rhodonite crystals within the fine-grained rhodonite - rhodochrosite assemblage, provide evidence that rhodonite is a primary Mn-bearing mineral that is later replaced by rhodochrosite. At Cirotan, rhodonite crystallized again after the formation of rhodochrosite. Thus the characteristics of the fluids varied several times during the formation of the dominant Mn-bearing mineral zone, and rhodonite and rhodochrosite alternated.

At Cirotan, brittle deformation events either caused brecciation (formation of the inner cockade, Mn-bearing mineral zone) or created openings (at the beginning of the final generation of comb quartz) (Genna et al. 1996). Two stages of fluid boiling were recorded by fluid inclusions, separated by periods where the fluids are single-phase ones (no boiling). These fluid-boiling events correspond to the formation of the breccia or to the openings, and are thus related to brittle behavior. It was not possible to study fluid inclusions in all the lay- ers of the cockade structure. However, boiling of the fluid is also indicated by the crystallization of platy calcite (Simmons \& Christenson 1990) and by the evolution of the habits of silica, from disordered and microscopic silica grains to well-crystallized quartz as the system reverts back toward its initial state (Henley \& Berger 2000). It is thus clear that such a cockade organization can be related to alternating periods with or without fluid boiling.

The depth of formation of epithermal deposits is usually shallow (some hundred meters). Thus to a first approximation the temperature corrections due to pressure are negligible. For non-boiling fluids, the temperatures of trapping can be considered as being roughly similar to the temperatures of homogenization. For boiling fluids, the lowest recorded temperature of homogenization is considered as the temperature of trapping. At Cirotan, the fluid-inclusion studies give $160^{\circ} \mathrm{C}$ as the temperature during the first boiling recorded at the end of the Mn-bearing mineral zone. During the formation of the first sequence of the quartz-sulfide zone, the fluid temperature increased from 170 to $255^{\circ} \mathrm{C}$. The lack of inclusions at the end of this quartz-sulfide zone that could be studied is compensated by the presence of a chlorite-group mineral. Using a chlorite geothermometer (Cathelineau \& Nieva 1985, modified by Zang \& Fyfe 1995), calculations give a crystallization temperature of $250-255^{\circ} \mathrm{C}$ for the chlorite, similar to the temperatures indicated by fluid inclusions at the end of the first sequence of the quartz-pyrite zone. A temperature of $180^{\circ} \mathrm{C}$ is then recorded at the beginning of the final generation of comb quartz. The temperature drop from 255 and $180^{\circ} \mathrm{C}$ observed after the formation of the quartz-sulfide zone and the indication of fluid boiling at the same time are considered as the indication of an isenthalpic boiling (Drummond 1981, Henley \& Hughes 2000). Using Drummond's curves, such a drop in temperature corresponds to the formation of $20 \%$ vapor at the depth of the sample studied. A similar isenthalpic boiling probably occurred during the formation of the Mn-bearing minerals. Unfortunately, the initial fluids were not found, and thus the initial temperature of the fluids before boiling is not known.

Using the boiling-point curve for the $\mathrm{H}_{2} \mathrm{O}-2 \mathrm{wt} \%$ $\mathrm{NaCl}$ system (Haas 1971) and an average density of 2.8 for the surrounding rocks, a minimum depth of $450 \mathrm{~m}$ is necessary to prevent the boiling of such fluids at 250$255^{\circ} \mathrm{C}$ under lithostatic pressure regime $\left(\mathrm{P}_{\text {fluid }}=\mathrm{P}_{\text {solid }}\right)$ (at the end of the quartz-sulfide zone). These results are in good agreement with the more general ones obtained previously by Nehlig \& Marcoux (1992) and Milési et al. (1994). These authors found evidence for a slight increase in temperature from 235 to $255^{\circ} \mathrm{C}$ from the initial stage to the final one in the Cirotan deposit, and they related this increase in temperature to the progressive uplift of magma that was marked by the appearance of $\mathrm{Sn}-\mathrm{W}-\mathrm{Bi}$-bearing minerals. 
The same conclusions can be drawn for the final generation of comb quartz from the two other deposits, Cavnic and Orcopampa. Their formation also is related to a boiling of the fluids, but here with a smaller drop in temperature. Moreover, at Orcopampa, despite the lack of studiable fluid inclusions in the first zone of the cockades, early boiling is suggested by the occurrence of the assemblage rhodonite - "adularia" - platy calcite replaced by a quartz-dominant assemblage (Browne \& Ellis 1970, Keith \& Muffler 1978, Simmons \& Christenson 1990).

Low-sulfidation epithermal deposits such as Cirotan, Cavnic and Orcopampa involve the circulation of neutral-pH, reduced, low-salinity (less than $10 \mathrm{wt} \% \mathrm{NaCl}$ eq.) and meteoric-water-dominant fluids. However, the presence of a magmatic-gas-rich $\left(\mathrm{CO}_{2}, \mathrm{H}_{2} \mathrm{~S}\right.$ and $\left.\mathrm{HCl}\right)$ component is demonstrated (Giggenbach 1992, Hedenquist \& Lowenstern 1994). Hydrothermal temperatures range from $<150$ to $300^{\circ} \mathrm{C}$. Under such conditions, base metals such as $\mathrm{Mn}$ and $\mathrm{Ag}$ are mostly transported as chloride complexes, e.g., $\mathrm{MnCl}_{2}{ }^{-}$and $\mathrm{AgCl}_{2}{ }^{-}$, whereas gold is transported in Cl-poor solutions as bisulfide complexes such as $\mathrm{Au}(\mathrm{HS})_{2}{ }^{-}$(Hedenquist \& Henley 1985). Fluid boiling, with possible hydraulic fracturing, is a critical process for metal deposition and acts as a strong physical and chemical trigger for mineralogical changes among the Mn-rich minerals. According to Gammons \& Seward (1996) (Fig. 5), the solubility of rhodonite is markedly retrograde. Thus rhodonite cannot precipitate during a simple episode of cooling. This mineral is more likely deposited in response to sudden increase in $\mathrm{pH}$ (fluid boiling) or decrease in chloride concentration (fluid dilution). The solubility of rhodochrosite is either prograde or retrograde, according to fluid salinity and temperature, and its precipitation could occur in response to cooling, as well as to a decrease in $\mathrm{H}^{+}, \mathrm{CO}_{2}$, or $\mathrm{Cl}^{-}$concentration. Thus assuming a constant $\mathrm{p}\left(\mathrm{CO}_{2}\right)$ value, Figure 5 indicates that rhodochrosite is far less soluble than rhodonite at low temperature $\left(<200^{\circ} \mathrm{C}\right)$, whereas it is more soluble at high temperature $\left(>250^{\circ} \mathrm{C}\right)$. However, a simple cooling cannot explain the replacement of rhodonite by rhodochrosite, because during boiling, the $\mathrm{CO}_{2}$ content of the liquid phase does not remain constant. Owing to the lack of fluid inclusions that can be studied, none of the characteristics of the fluids (state, temperature, composition) during the deposition of the Mn minerals are known. However, we can assume that the alternating deposition of rhodonite and rhodochrosite may well be due to changes in temperature, $\mathrm{pH}$ and $\mathrm{p}\left(\mathrm{CO}_{2}\right)$ in relation to episodes of boilings at a temperature close to $250^{\circ} \mathrm{C}$.

\section{ACKNOWLEDGEMENTS}

This paper is a part of a scientific cooperation program between the BRGM (DR/RM, Orléans France) and the Université Henri Poincaré (UMR G2R, Nancy
France). It was supported by the GdR "Métallogénie". The authors thank J.-P. Milési and L. Bailly (BRGM) for fruitful discussions, R.F. Martin, J.F. Slack, and the two anonymous referees he consulted for all their comments, which greatly improved this paper.

\section{REFERENCES}

Bailly, L., Milési, J.P., Leroy, J.L. \& MarcouX, E. (1998): Les minéralisations épithermales à $\mathrm{Au}-\mathrm{Cu}-\mathrm{Zn}-\mathrm{Sb}$ du district de Baia Mare (Nord Roumanie). Nouvelles données minéralogiques et microthermométriques. C.R. Acad. Sci. 327(6), Sér. II, 385-390.

BODNAR, R.J. (1993): Revised equation and table for determining the freezing point depression of $\mathrm{H}_{2} \mathrm{O}-\mathrm{NaCl}$ solutions. Geochim. Cosmochim. Acta 57, 683-684.

Browne, P.R.L. \& ElLis, A.J. (1970): The Ohaaki-Broadlands hydrothermal area, New Zealand: mineralogy and related geochemistry. Am. J. Sci. 269, 97-131.

Cathelineau, M. \& Nieva, D. (1985): A chlorite solid solution geothermometer. The Los Azufres (Mexico) geothermal system. Contrib. Mineral. Petrol. 91, 235-244.

Cooke, D.R., McPhail, D.C. \& Bloom, M.S. (1996): Epithermal gold mineralization, Acupan, Baguio District, Philippines: geology, mineralization, alteration, and the thermochemical environment of ore deposition. Econ. Geol. 91, 243-272.

Drummond, S.E., JR. (1981): Boiling and Mixing of Hydrothermal Fluids: Chemical Effects on Mineral Precipitation. Ph.D. thesis, Pennsylvania State Univ., University Park, Pennsylvania.

Gammons, C.H. \& Seward, T.H. (1996): Stability of manganese (II) chloride complexes from 25 to $300^{\circ} \mathrm{C}$. Geochim. Cosmochim. Acta 60, 4295-4311.

Genna, A., JébraK, M., Marcoux, E. \& Milési, J.P. (1996): Genesis of cockade breccias in the tectonic evolution of the Cirotan epithermal gold system, West Java. Can. J. Earth Sci. 33, 93-102.

GiBson, P.C. (1992): The Calera Vein System, Orcopampa District, Peru: Association of Tectonism, Magmatism, and Hydrothermal Activity in the Formation of Bonanza AgAu Mineralization. Ph.D. dissertation, Univ. of Nevada, Reno, Nevada.

McKee, E.H., Noble, D.C. \& Swanson, K.E. (1995): Timing and interrelation of magmatic, tectonic, and hydrothermal activity at the Orcopampa district, southern Peru. Econ. Geol. 90, 2317-2325.

GiggenbaCH, W.F. (1992): Magma degassing and mineral deposition in hydrothermal systems along convergent plate boundaries. Econ. Geol. 87, 1927-1944.

GRANCEA, L. (1998): Etude des fluides associés aux gisements épithermaux neutres (low-sulfidation). Le district de Baia 
Mare, Roumanie. Rapport DEA, Univ. Henri PoincaréNancy 1, France.

HAAS, J.L., JR. (1971): The effect of salinity on the maximum thermal gradient of a hydrothermal system at hydrostatic pressure. Econ. Geol. 66, 940-946.

Hedenquist, J.W. \& Henley, R.W. (1985): Hydrothermal eruptions in the Waiotapu geothermal system, New Zealand: their origin, associated breccias, and relation to precious metal mineralization. Econ. Geol. 80, 1640-1668.

\& LOWENSTERN, J.B. (1994): The role of magmas in the formation of hydrothermal ore deposits. Nature 370, 519-527.

HENLEy, R.W. \& BERGER, B.R. (2000): Self-ordering and complexity in epizonal mineral deposits. Annu. Rev. Earth Planet. Sci. 28, 669-721.

\& Hughes, G.O. (2000): Underground fumaroles: "excess heat" effects in vein formation. Econ. Geol. 95, 453-466.

KeITH, T.E.C. \& MuffleR, L.J.P. (1978): Minerals produced during cooling and hydrothermal alteration of ash flow tuff from Yellowstone drill hole Y-5. J. Volcanol. Geotherm. Res. 3, 373-402.

Lucchetti, G. (1991): Tephroite from the Val Graveglia metacherts (Liguria, Italy): mineral data and reactions for Mn-silicates and Mn-Ca-carbonates. Eur. J. Mineral. 3, 63-68.

Marcoux, E., Milési, J.P., Sitorus, T. \& SimanduuntaK, M. (1996): The epithermal Au-Ag-(Mn) deposit of Pongkor (West Java, Indonesia). Indonesian Mining J. 2, 1-17.

Sohearto, S. \& Rinawan, R. (1993): Noteworthy mineralogy of $\mathrm{Au}-\mathrm{Ag}-\mathrm{W}-\mathrm{Sn}$ (Bi) epithermal deposit of Cirotan, western Java, Indonesia. Can. Mineral. 31, 727-744.
Milési, J.P., Marcoux, E., Nehlig, P., Sunarya, Y., Sukandar, A. \& Felenc, J. (1994): Cirotan, west Java, Indonesia: a 1.7 Ma hybrid epithermal $\mathrm{Au}-\mathrm{Sn}-\mathrm{W}$ deposit. Econ. Geol. 89, 227-245.

, Sitorius, T., Simandunntak, M., LEROY, J.L. \& BAILLY, L. (1999): Pongkor (west Java, Indonesia): a Pliocene supergene-enriched epithermal AuAg-(Mn) deposit. Mineral. Deposita 34, 131-149.

Nehlig, P. \& Marcoux, E. (1992): Le gisement d'or épithermal de Cirotan (Ouest Java, Indonésie): contraintes microthermométriques. C.R. Acad. Sci. Paris 315, Sér. II, 821-827.

Piantone, P., Grancea, L., Leroy. J.L., Bailly, L., Marias, Z., Nehlig, P. \& MARCouX, E. (1999): Fluid inclusion and isotope study of the Cavnic epithermal deposit (Romania). In Mineral Deposits: Processes to Processing (C.J. Stanley et al., eds.). A.A. Balkema Publ., Rotterdam, The Netherlands (79-82).

Plumlee, G.S. \& Whitehouse-Veaux, P.H. (1994): Mineralogy, paragenesis, and mineral zoning in the Bulldog Mountain vein system, Creede district, Colorado. Econ. Geol. 89, 1883-1905.

Simmons, S.F. \& Christenson, B.C. (1990): Platy calcite is an indicator of boiling in epithermal deposits: evidence from New Zealand geothermal systems. Geol. Soc. Am., Abstr. Programs 22, 42.

ZANG, W. \& FYFE, W.S. (1995): Chloritization of the hydrothermally altered bedrock at the Igarapé Bahia gold deposit, Carajàs, Brazil. Mineral. Deposita 30, 30-38.

Received November 11, 1999, revised manuscript accepted September 13, 2000. 